\title{
TEKNIK NON TES: \\ Telaah atas Fungsi Wawancara dan Kuesioner dalam Evaluasi Pendidikan
}

\author{
Oleh: Sitti Mania*
}

\begin{abstract}
Evaluation in the world education constitutes an absolute activity, because, evaluation of the development students learning achievement, evaluation subject can be read. Besides that, through evaluation-teacher, lecturer, and manager who involve in a educational institution can know how far and big are the development and growth of teaching program that held in order to achieve the goal which is formulated. The evaluation can be done by using test technique and non test one.non test technique is very various, but this writing only explains two kinds namely; interview and questionnaire.
\end{abstract}

KEYWORDS: Evaluasi, wawancara, kuesioner, pendidikan

KEGIATAN evaluasi dalam rangka menilai hasil belajar peserta didik pada umumnya tertuang dalam bentuk tes dengan berbagai variasinya, walaupun dalam praktek, teknik tes lebih sering dipergunakan. Pernyataan di atas tidaklah mengandung arti bahwa teknik tes merupakan satusatunya teknik yang dapat digunakan dalam kegiatan evaluasi, tetapi hasil belajar siswa juga dapat diketahui, ditelusuri, dan dinilai dengan menggunakan teknik non tes.

Dengan teknik non tes, penilaian hasil belajar peserta didik dilakukan dengan tanpa "menguji" peserta didik, melainkan dengan melakukan pengamatan secara sistematis atau dikenal dengan observasi ${ }^{1}$, wawancara, menyebarkan angket (kuesioner), memeriksa atau meneliti dokumendokumen ${ }^{2}$ skala (baik skala sikap maupun skala penilaian) ${ }^{3}$, studi kasus ${ }^{4}$, dan sosiometri ${ }^{5}$.

Penggunaan teknik non tes untuk menilai hasil dan proses belajar masih sangat terbatas jika dibandingkan dengan penggunaan tes. Padahal teknik ini sifatnya lebih komprehensif, dalam artian dapat digunakan untuk menilai berbagai aspek dari individu sehingga penilaian tidak hanya

*Magister dalam bidang Pemikiran Pendidikan ini adalah lulusan Program Pascasarjana UIN Sunan Kalijaga, Yogyakarta. Saat ini ia sebagai dosen tetap Fakultas Tarbiyah dan Keguruan UIN Alauddin Makassar. 
terbatas pada aspek kognitif, tetapi juga mengungkap aspek afektif dan psikomotoris.

Guna menyempitkan persoalan, maka penulis hanya memfokuskan pembahasan pada dua jenis teknik non tes yang telah disebut di atas, yakni wawancara dan kuesioner.

Berangkat dari paparan di atas, ada beberapa rumusan masalah yang akan dijadikan acuan kerja. Pertama, apa yang dimaksud dengan wawancara dan kuesioner dalam hubungannya dengan evaluasi pendidikan dan pengajaran? Kedua, bagaimana fungsi wawancara dan kuesioner dalam evaluasi pendidikan dan pengajaran? Ketiga, bagaimana mengolah data yang diperoleh dari kegiatan wawancara dan kuesioner?

\section{HUBUNGAN WAWANCARA DENGAN EVALUASI PENDIDIKAN}

Wawancara secara umum dapat diartikan sebagai cara untuk menghimpun data atau bahan-bahan keterangan yang dilaksanakan dengan jalan tanya jawab lisan secara sepihak, berdasarkan tujuan yang telah ditetapkan. ${ }^{6}$ Dikatakan sepihak karena dalam wawancara, informan tidak diberi kesempatan sama sekali untuk mengajukan pertanyaan-pertanyaan. ${ }^{7}$

Wawancara sebagai alat penilaian dalam pendidikan dan pengajaran dapat dipergunakan untuk menilai hasil dan juga proses belajar. Terdapat dua jenis wawancara yang dapat dipergunakan sebagai alat penilaian: pertama, wawancara terpimpin, yang juga dikenal dengan wawancara berstruktur atau wawancara sistematis; dan kedua, wawancara tidak terpimpin, yang juga dikenal dengan wawancara sederhana, wawancara tidak sistematis atau wawancara bebas. ${ }^{8}$

Dalam wawancara terpimpin, kemungkinan jawaban telah disiapkan sehingga siswa tinggal mengategorikan kepada alternatif jawaban yang telah dibuat. Dengan kata lain, wawancara jenis ini dilakukan dengan berpegang pada panduan wawancara yang butir-butir pertanyaannya terdiri dari hal-hal yang dianggap perlu berdasarkan tujuan pelaksanaan wawancara.

Sedangkan wawancara jenis kedua, pewawancara selaku evaluator (guru, dosen, dan lain-lain) mengajukan pertanyaan-pertanyaan kepada peserta didik tanpa dikendalikan oleh panduan atau pedoman tertentu, dan siswa dengan bebas mengemukakan jawaban-jawabannya.

Kedua jenis wawancara yang dijelaskan di atas, dari segi pelaksanaan dan pengolahannya, masing-masing memiliki kelebihan dan kekurangan. Pada wawancara terpimpin, karena kemungkinan jawaban telah disiapkan, maka siswa dapat secara langsung memilih salah satu jawaban alternatif yang telah ada. Oleh karena itu, mudah bagi evaluator dalam mengolah 
dan menganalisisnya untuk kemudian menarik kesimpulan. Namun, kekurangannya adalah siswa tidak bebas mengemukakan pendapat, karena dipasung oleh alternatif jawaban yang telah disiapkan terlebih dahulu oleh evaluator.

Sedangkan pada wawancara tidak terpimpin, siswa bebas mengemukakan pendapat, komentar, dan aspirasi karena evaluator atau pewawancara tidak menyediakan alternatif jawaban. Dengan demikian, informasi yang dapat diperoleh lebih lengkap dan padat. Akan tetapi, kekurangan yang dimiliki oleh wawancara jenis ini terletak pada penganalisisan data hasil wawancara, yaitu beraneka ragamnya jawaban yang diperoleh. Jawaban siswa tidak bisa langsung ditafsirkan, tetapi perlu analisis dalam bentuk dimensi-dimensi jawaban, sesuai dengan aspek yang diungkapkan.

Terlepas dari kelebihan dan kekurangan yang dimiliki oleh dua jenis wawancara tersebut, pada dasarnya wawancara sebagai alat evaluasi dalam dunia pendidikan memiliki nilai plus, karena pewawancara selaku evaluator dapat melakukan kontak langsung dengan peserta didik yang akan dinilai, sehingga memungkinkan untuk mendapatkan hasil penilaian yang lebih mendalam.

Di samping itu, untuk dapat mencatat jawaban siswa secara lengkap, dan untuk memudahkan dalam pengkategorian serta penganalisisan jawaban-jawaban peserta didik, kegiatan wawancara dapat dilengkapi dengan alat bantu seperti alat perekam suara.

Menurut Nana Sudjana9 ${ }^{9}$, dalam melaksanakan wawancara, ada tiga aspek yang harus diperhatikan.

\section{Tahap Awal Pelaksanaan Wawancara}

Perhatian terhadap aspek yang pertama ini bertujuan untuk mengkondisikan situasi wawancara. Pernyataan ini mengandung arti bahwa evaluator harus menciptakan situasi yang mengungkapkan suasana keakraban sehingga siswa tidak merasa takut, yang pada akhirnya dapat mengemukakan jawaban atau pendapatnya secara bebas.

\section{Penggunaan Pertanyaan}

Aspek yang kedua ini mengandung pengertian bahwa pertanyaan diajukan secara bertahap dan sistematis berdasarkan kisi-kisi yang telah dibuat sebelumnya. Apabila menggunakan wawancara terpimpin, maka pewawancara mengajukan pertanyaan beserta dengan alternatif jawabannya. Siswa kemudian mengemukakan pendapatnya, lalu pendapat tersebut diklasifikasikan ke dalam alternatif jawaban yang telah ada. Lain halnya ketika menggunakan wawancara tidak terpimpin, evaluator mengajukan pertanyaan dan siswa menjawab dengan bebas. 


\section{Pencatatan Hasil Wawancara}

Pencatatan hasil wawancara sebaiknya dilakukan saat wawancara berlangsung. Hal ini dimaksudkan agar jawaban responden atau siswa tidak dilupa. Terhadap wawancara terpimpin, pencatatannya cukup mudah sebab tinggal memberikan tanda pada alternatif jawaban. Sedangkan pada wawancara tidak terpimpin, pokok-pokok isi jawaban siswa perlu dicatat pada lembaran tersendiri.

Selain ketiga aspek di atas, masih ada satu hal penting yang juga mesti diperhatikan ketika menggunakan wawancara sebagai alat evaluasi, yaitu pedoman wawancara. Pedoman wawancara tersebut perlu disusun sedemikian rupa sehingga wawancara bisa berlangsung dengan baik dan tepat sasaran. Pedoman wawancara tersebut disusun dengan menempuh langkah-langkah sebagai berikut:

- Tentukan tujuan yang ingin dicapai dari kegiatan wawancara tersebut. Misalnya, untuk mengetahui cara belajar siswa yang berprestasi bagus.

- Tentukan aspek-aspek apa saja yang ingin diungkap melalui kegiatan tersebut. Kemudian aspek-aspek tersebut dijadikan dasar dalam menyusun materi pertanyaan.

- Tentukan jenis wawancara apa yang akan digunakan, terpimpin atau tidak terpimpin atau kombinasi dari kedua jenis tersebut.

- Buat pertanyaan sesuai dengan jenis wawancara yang akan digunakan.

- Sebaiknya buat pedoman mengolah dan menafsirkan hasil wawancara.

Dengan memperhatikan dan mengikuti pedoman wawancara yang disebutkan di atas, diharapkan pelaksanaan wawancara dapat berjalan dengan baik sehingga fungsinya sebagai alat bantu dalam evaluasi pendidikan dan pengajaran dapat tercapai dengan baik pula.

\section{HUBUNGAN KUESIONER DENGAN EVALUASI PENDIDIKAN}

Kuesioner atau angket adalah sebuah daftar pertanyaan yang harus diisi oleh orang yang akan dinilai (responden). Melalui kuesioner, dapat diketahui keadaan diri, pengalaman, pengetahuan, sikap atau pendapat responden. ${ }^{10}$

Penggunaan kuesioner sebagai alat bantu dalam rangka penilaian hasil belajar siswa, pelaksanannya berbeda dengan wawancara. Melalui kuesioner, pengumpulan data sebagai bahan penilaian hasil belajar siswa jauh lebih praktis, menghemat waktu dan tenaga, karena penilai tidak perlu berhadapan langsung dengan peserta didik atau dengan pihak lainnya seperti pada wawancara. Hal inilah yang menjadikan kelebihan kuesioner dari wawancara. Namun, kelemahannya adalah karena jawaban- 
jawaban yang diperoleh sering tidak obyektif, tidak sesuai dengan fakta yang sebenarnya, terlebih lagi jika pertanyaan-pertanyaan yang diajukan kurang spesifik, sehingga besar peluang bagi responden memberikan jawaban yang dperkirakan akan melegakan pihak penilai.

Menurut Suharsimi Arikunto, macam kuesioner dapat ditinjau dari beberapa segi: 11

1. Ditinjau dari segi siapa yang menjawab, maka kuesioner ada dua:

a. Kuesioner langsung

Dikatakan kuesioner langsung, jika kuesioner tersebut diisi langsung oleh orang yang akan dimintai jawaban tentang dirinya.

b. Kuesioner tidak langsung

Kuesioner tidak langsung adalah kuesioner yang diisi oleh bukan orang yang dicari keterangannya, misalnya para orangtua peserta didik.

2. Ditinjau dari segi cara menjawabnya. Jika ditinjau dari segi cara menjawabnya, maka kuesioner dapat dibedakan atas:

a. Kuesioner tertutup

Kuesioner tertutup adalah kuesioner yang disusun dengan menyediakan alternatif jawaban sehingga responden tinggal memberi tanda pada jawaban yang dipilih.

b. Kuesioner terbuka

Kuesioner jenis ini disusun sedemikian rupa sehingga para responden bebas mengemukakan pendapatnya.

Tujuan pertama penggunaan kuesioner dalam kegiatan atau proses pengajaran adalah untuk memperoleh data mengenai latar belakang siswa sebagai salah satu bahan dalam menganalisis tingkah laku dan proses belajar mereka. Karena untuk tujuan ini dapat dibuat dalam bentuk pertanyaan terbuka ataupun tertutup yang mengungkapkan antara lain:

- Identitas siswa (jenis kelamin, usia, agama, keadaan fisik, hobi, mata pelajaran yang disenangi).

- Latar belakang keluarga siswa (pekerjaan orangtua, pendidikan orangtua, anak ke berapa, status anak-kandung, tiri, atau angkat.

- Latar belakang lingkungan siswa (alamat tempat tinggal, status perumahan, suasana religi, pemanfaatan waktu senggang, dan lain-lain.

Tujuan kedua adalah untuk memperoleh data mengenai hasil belajar yang dicapai peserta didik dan proses belajar yang ditempuhnya. Untuk tujuan ini pertanyaan-pertanyaan dikemas untuk mengungkap beberapa aspek seperti hasil belajar yang dicapainya, kesulitan belajar, fasilitas belajar, bimbingan yang dibutuhkan, motivasi dan minat belajar, sikap 
terhadap mata pelajaran, pandangan peserta didik terhadap proses mengajar dan sikap terhadap guru/dosen.

Tujuan ketiga adalah untuk memperoleh data sebagai bahan dalam menyusun kurikulum dan program belajar-mengajar. Untuk tujuan ini, pertanyaan-pertanyaan dikemas dengan tujuan mengungkap aspek-aspek yang berkenaan dengan luas bahasan, tingkat kesulitan bahan, cara guru/ dosen mengajar, kesinambungan bahan pelajaran, sistem penilaian atau ujian, buku pelajaran, alat peraga dan media, laboratorium, kegiatan ekstra kurikuler, lama belajar, kegiatan siswa/mahasiswa dan sebagainya.

Mengingat fungsi dan tujuan kuesioner sebagai alat evaluasi hasil belajar sangat vital, maka penyusunan kuesioner sebaiknya mengikuti petunjuk teknis sebagai berikut:

- Hendaknya dimulai dengan pengantar yang isinya permohonan untuk mengisi kuesioner sambil dijelaskan maksud dan tujuannya.

- Guru/dosen perlu menjelaskan petunjuk atau cara mengisinya. Kalau perlu berikan contoh.

- Dimulai dengan pertanyaan tentang identitas responden. Sebaiknya tidak diminta mencantumkan nama, cukup jenis kelamin, usia, pendidikan, pengalaman dan lain-lain yang ada kaitannya dengan tujuan kuesioner.

- Isi pertanyaan sebaiknya dibuat beberapa kategori atau bagian sesuai dengan variabel yang diungkapkan sehingga mudah mengolahnya.

- Pertanyaan dibuat singkat dan jelas sehingga tidak membingungkan dan salah penafsiran.

- Antara pertanyaan yang satu dengan pertanyaan lain harus terdapat hubungan sehingga tampak logikanya dalam satu rangkaian yang sistematis.

- Diusahakan agar kemungkinan jawaban, kalimat atau rumusannya tidak lebih panjang dari pertanyaan.

- Kuesioner yang terlalu banyak atau terlalu panjang akan melelahkan dan membosankan responden sehingga pengisiannya tidak obyektif lagi. Dengan demikian hendaknya dihindari kuesioner yang seperti itu.

- Sebaiknya kuesioner diakhiri dengan tanda tangan si pengisi untuk menjamin keabsahan jawabannya. ${ }^{12}$

Senada dengan pendapat Anas Sudijono di atas, Suharsimi Arikunto dalam bukunya Prosedur Penelitian mengemukakan, sebelum kuesioner disusun terlebih dahulu harus melalui prosedur sebagai berikut:

- Merumuskan tujuan yang akan dicapai dengan kuesioner.

- Mengidentifikasi variabel yang akan dijadikan sasaran kuesioner.

- Menjabarkan setiap variabel menjadi sub-variabel yang lebih spesifik 
dan tunggal.

- Menentukan jenis data yang akan dikumpulkan, sekaligus untuk menentukan teknik analisisnya. ${ }^{13}$

Kiranya dengan mempertimbangkan petunjuk teknis dan prosedur penyusunan kuesioner di atas, evaluator dalam hal ini guru atau dosen dapat menemukan fungsi vital dari kuesioner sebagai alat bantu penilaian dalam dunia pendidikan dan pengajaran.

\section{PENGOLAHAN DATA HASIL WAWANCARA DAN KUESIONER}

Seperti telah diuraikan di atas, bahwa proses dan hasil belajar tidak hanya bisa diukur dengan tes, tetapi juga dengan alat ukur non tes. Pengolahan data hasil non tes bisa menggunakan cara-cara seperti pada pengolahan data menggunakan tes, juga dapat menggunakan cara-cara lain seperti persen, modus, dan peringkat terutama bila hasil pengukuran menghasilkan data nominal atau ordinal.

Untuk pengolahan dan analisis data hasil wawancara dan kuesioner pada umumnya dimulai dengan mencari frekuensi jawaban responden untuk setiap alternatif yang ada pada setiap pertanyaan. Frekuensi yang paling tinggi ditafsirkan sebagai kecenderungan jawaban alat ukur tersebut. Sebaliknya, frekuensi yang paling rendah dapat ditafsirkan sebagai kecenderungan jawaban yang tidak menggambarkan pendapat kebanyakan responden.

Sebagai contoh ${ }^{14}$, melalui kuesioner ataupun wawancara akan diungkap pandangan siswa/mahasiswa mengenai guru/dosen yang diharapkan dalam kemampuan mengajar serta hubungan guru/dosen dengan siswa/ mahasiswa. Kuesioner atau wawancara kemudian diajukan kepada 40 orang siswa dengan pertanyaan sebagai berikut:

1. Guru/dosen yang Anda harapkan adalah guru/dosen yang:

a. Menguasai bahan pelajaran atau pandai dalam bidang ilmunya.

b. Cara menjelaskan dapat dipahami sekalipun tidak terlalu pandai.

c. Pandai dalam bidang ilmunya dan dapat menjelaskannya kepada siswa dengan baik.

2. Pada waktu mengajarkan bahan pelajaran:

a. Sebaiknya dimulai dari yang umum, kemudian dibahas secara khusus.

b. Sebaiknya dimulai dari yang khusus, kemudian menuju kepada yang umum.

c. Dimulai dari mana saja asal dijelaskan secara sistematis.

3. Menurut pendapat Anda, hubungan guru/dosen dengan siswa/mahasiswa di dalam kelas: 

a. Harus menjaga jarak agar tidak kehilangan wibawa.
b. Tidak perlu menjaga jarak asal dalam batas-batas pendidikan.
c. Mencerminkan hubungan orangtua dengan anak-anaknya.

4. Untuk membina hubungan guru/dosen dengan siswa/mahasiswa, sebaiknya guru/dosen berusaha untuk:

a. Memahami pribadi para siswa/mahasiswanya.

b. Melibatkan diri dalam berbagai kegiatan yang dilaksanakan oleh siswa/mahasiswa.

c. Bergaul dengan siswa/mahasiswa dalam berbagai kesempatan.

Kuesioner yang telah diisi oleh responden kemudian diperiksa dan diolah dengan menghitung frekuensi jawaban seluruh siswa terhadap setiap pertanyaan tersebut. Misalnya, hasil pemeriksaan tersebut adalah sebagai berikut:

Frekuensi Jawaban Siswa

Mengenai Masalah Kemampuan Guru Mengajar ( $\mathrm{n}=40)$

\begin{tabular}{llll}
\hline Masalah yang Diungkap & f & $\%$ & Peringkat Jawaban
\end{tabular}

1. Kemampuan mengajar

1.1. Kemampuan mengajar

$\begin{array}{lrrr}\begin{array}{lrl}\text { a. Menguasai bahan } \\ \text { b.Mampu menjelaskan bahan }\end{array} & 4 & 10 & 3 \\ \begin{array}{l}\text { c. Menguasai bahan dan } \\ \begin{array}{l}\text { mampu menjelaskannya } \\ \text { mampu }\end{array}\end{array} & 30 & 60 & 2\end{array}$

1.2. Prosedur mengajarkan bahan pelajaran

$\begin{array}{lrrr}\text { a. Dimulai dari yang umum } & 10 & 25 & 2 \\ \text { b. Dimulai dari yang khusus } & 6 & 15 & 3 \\ \text { c. Harus sistematis } & 24 & 60 & 1\end{array}$

2. Dan seterusnya ...

Dari data di atas dapat dipahami bahwa kemampuan guru/dosen mengajar yang diharapkan oleh siswa/mahasiswa adalah guru/dosen yang menguasai bahan pelajaran dan dapat menjelaskannya dengan baik agar dapat dipahami oleh siswa/mahasiswa, sedangkan prosedur yang diharapkan oleh siswa/mahasiswa harus sistematis. 


\section{CATATAN AKHIR:}

1. Observasi merupakan cara menghimpun keterangan atau data yang dilakukan dengan mengadakan pengamatan dan pencatatan secara sistematis terhadap fenomena yang sedang dijadikan sasaran pengamatan. Observasi dalam dunia pendidikan dan pengajaran dipergunakan untuk menilai ranah psikomotor siswa. Lihat Nasution, Metode Research, Jakarta: Bumi Aksara, 2000, h. 106; lihat juga, Ngalim Purwanto, Prinsip-prinsip dan Teknik Evaluasi Pengajaran, Bandung: PT. Remaja Rosdakarya, 1987, h. 149.

2. Dokumen yang dimaksud adalah dokumen yang memuat informasi mengenai riwayat hidup peserta didik. Dalam dunia pendidikan dan pengajaran cara ini dipergunakan untuk melengkapi data mengenai kemajuan, perkembangan atau keberhasilan peserta didik. Di samping dokumen mengenai peserta didik itu sendiri, juga terkadang dibutuhkan dokumen tentang orangtua peserta didik serta lingkungannya. Lihat Anas Sudijono, Pengantar Evaluasi Pendidikan, Jakarta: PT. Raja Grafindo Persada, 1998, h. 32.

3. Skala sikap digunakan untuk mengukur sikap siswa terhadap obyek tertentu. Sikap di sini meliputi tiga komponen, yakni kognisi, afeksi, dan konasi. Skala penilaian bertujuan untuk mengukur keterampilan atau perilaku peserta didik melalui pernyataan perilaku individu pada suatu titik kontinum atau suatu kategori yang bermakna nilai. Lihat Nana Sudjana, Penilaian Hasil Proses Belajar Mengajar, Bandung: PT. Remaja Rosdakarya, 1995, h. 68 dan 77.

4. Studi kasus adalah suatu inkuiri empiris yang mnyelidiki fenomena di dalam konteks kehidupan nyata yang batas-batas antara fenomena dan konteks tak tampak dengan jelas dan di mana multi sumber bukti dimanfaatkan. Robert K. Yin, Studi Kasus (Desain dan Metode), Jakarta: PT. RajaGrafindo Persada, 2000, h. 18. Dalam dunia pendidikan, studi kasus berfungsi untuk mempelajari secara intensif seorang siswa yang dipandang mengalami kasus tertentu, seperti siswa yang selalu gagal belajar dan sebagainya. Nana Sudjana, Penilaian Hasil Proses Belajar Mengajar, h. 94.

5. Teknik sosiometri adalah cara untuk mengetahui kemampun siswa dalam menyesuaikan diri, terutama hubungan sosial siswa dengan teman sekelasnya, sehingga dengan menggunakan cara ini dapat diketahui posisi siswa dalam hubungan sosialnya dengan siswa lain. Nana Sudjana, Penilaian Hasil Proses Belajar Mengajar, h. 98.

6. Anas Sudijono, Pengantar Evaluasi Pendidikan, h. 82. Lihat juga Suharsimi Arikunto, Dasar-dasar Evaluasi Pendidikan, Jakarta: Bumi Aksara, 1997, h. 27.

7. Anas Sudijono, Pengantar Evaluasi Pendidikan, h. 82.

8. Anas Sudijono, Pengantar Evaluasi Pendidikan, h. 82.

9. Nana Sudjana, Penilaian Hasil Proses Belajar Mengajar, h. 68.

10. Suharsimi Arikunto, Dasar-dasar Evaluasi Pendidikan, h. 24.

11. Suharsimi Arikunto, Dasar-dasar Evaluasi Pendidikan, h. 25.

12. Anas Sudijono, Pengantar Evaluasi Pendidikan, h. 71-72.

13. Suharsimi Arikunto, Prosedur Penelitian Suatu Pendekatan dan Praktek, Jakarta: PT. Rineka Cipta, 1997, h. 200.

14. Contoh penggunaan wawancara dan kuesioner beserta cara pengolahannya yang tertera di atas dikutip dari buku Nana Sudjana, Penilaian Hasil Proses Belajar Mengajar, h. 128-129. 


\section{DAFTAR PUSTAKA:}

Arikunto, Suharsimi., Dasar-dasar Evaluasi Pendidikan, Jakarta: Bumi Aksara, 1997. Prosedur Penelitian Suatu Pendekatan dan Praktek, Jakarta: PT. Rineka Cipta, 1997.

K. Yin, Robert., Studi Kasus (Desain dan Metode), Jakarta: PT. RajaGrafindo Persada, 2000.

Nasution, Metode Research, Jakarta: Bumi Aksara, 2000.

Nurkancana, Wayan dan P. P. N. Sunartana, Evaluasi Pendidikan, Surabaya: Usaha Nasional, 1986.

Purwanto, Ngalim, Prinsip-prinsip dan Teknik Evaluasi Pengajaran, Bandung: PT. Remaja Rosdakarya, 1987.

Sudijono, Anas, Pengantar Evaluasi Pendidikan, Jakarta: PT. Raja Grafindo Persada, 1998.

Sudjana, Nana, Penilaian Hasil Proses Belajar Mengajar, Bandung: PT. Remaja Rosdakarya, 1995.

-------, Penelitian dan Penilaian Pendidikan, Bandung: Sinar Baru, 1989.

Suilverius, Suke, Evaluasi dan Umpan Balik, Jakarta: Rasindo, t.th. 